

\section{Daftar Isi (Table of Content) Journal of Government
Civil Society}

\begin{tabular}{|c|c|}
\hline \multirow{3}{*}{$1-30$} & $\begin{array}{l}\text { The Application of Social Movement as a Form of Digital Advocacy: Case of } \\
\text { \#TolakRUUPermusikan }\end{array}$ \\
\hline & Muhammad Ananda Alifiarry ${ }^{1}$, Bevaola Kusumasari ${ }^{1}$ \\
\hline & $\begin{array}{l}\left({ }^{1} \text { Department of Public Policy and Management, Faculty of Social and Political Sciences, }\right. \\
\text { Universitas Gadjah Mada, Indonesia) }\end{array}$ \\
\hline \multirow{3}{*}{$31-50$} & $\begin{array}{l}\text { Urban Resilience Strategy in the Climate Change Governance in Makassar } \\
\text { City, Indonesia }\end{array}$ \\
\hline & $\begin{array}{l}\text { Ihyani Malik }{ }^{1} \text {, Andi Luhur Prianto }{ }^{2} \text {, Abdillah Abdillah², Zaldi Rusnaedy }{ }^{3} \text {, } \\
\text { Andi Annisa Amalia }{ }^{4}\end{array}$ \\
\hline & $\begin{array}{l}\text { (' Department of Public Administration, Universitas Muhammadiyah Makassar, Indonesia) } \\
\text { (' Department of Government Studies, Universitas Muhammadiyah Makassar, Indonesia) } \\
\text { ( }{ }^{3} \text { Department of Government Studies, Universitas Pancasakti Makassar, Indonesia) } \\
\text { ( }{ }^{4} \text { Department of Architecture, Faculty of Engineering, Universitas Muhammadiyah } \\
\text { Makassar, Indonesia) }\end{array}$ \\
\hline \multirow{3}{*}{$51-62$} & $\begin{array}{l}\text { Collaboration Governance in The Development of Natural Based Tourism } \\
\text { Destinations }\end{array}$ \\
\hline & 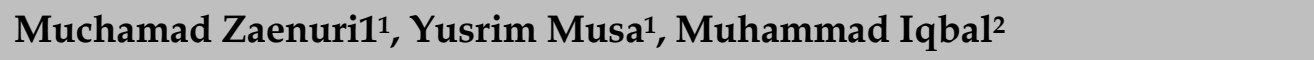 \\
\hline & $\begin{array}{l}\text { (1 Department of Government Affairs and Administration Universitas Muhammadiyah } \\
\text { Yogyakarta, Indonesia) } \\
\text { (2 Department of Political Science National Cheng Kung University, Taiwan, Province of } \\
\text { China) }\end{array}$ \\
\hline \multirow{3}{*}{$63-78$} & $\begin{array}{l}\text { Analysis of Mind Patterns and Work Culture in Government of West } \\
\text { Pasaman District }\end{array}$ \\
\hline & $\begin{array}{l}\text { Sri Andri Yani1 }{ }^{1} \text {, Etika Khairina1, Suswanta1, Mochammad Iqbal } \\
\text { Fadhlurrohman' }\end{array}$ \\
\hline & (1 Governmental Studies, Universitas Muhammadiyah Yogyakarta, Indonesia) \\
\hline \multirow{2}{*}{$79-90$} & $\begin{array}{l}\text { The Influence of Social Media (Instagram) of Bantul's General Election } \\
\text { Commissions on Voters Participation in the } 2019 \text { Elections }\end{array}$ \\
\hline & $\begin{array}{l}\text { Agus Priyanto', Eko Priyo Purnomo }{ }^{1,2} \text {, Mochammad Iqbal } \\
\text { Fadhlurrohman }^{1} \text {, Herry Fahamsyah", Etika Khairina }\end{array}$ \\
\hline
\end{tabular}


(1 Departement of Government Affairs and Administration, Universitas Muhammadiyah Yogyakarta, Indonesia)

(2 Jusuf Kalla School of Government, Universitas Muhammadiyah Yogyakarta, Indonesia)

Model Implementation Trap of Policy New Student Acceptance Zoning System in Makassar City

91 - 106 Nuryanti Mustari' ${ }^{1}$, Rudi Hardi ${ }^{1}$, Amir Muhiddin ${ }^{1}$

( ${ }^{1}$ Department of Government Studies, Faculty of Social and Political Sciences, Universitas Muhammadiyah Makassar, Indonesia)

Collaborative Urban Governance Model in Environmental Management of Industrial Area

Tri Sulistyaningsih"1, Saiman', Nofianda Fatimah Azzahra1, Nanda

$107-126$ Adityawan'2, Mohammad Jafar Loilatu ${ }^{3}$

( ${ }^{1}$ Department of Government Studies, Universitas Muhammadiyah Malang Indonesia) (2 Civil Engineering, Sepuluh Nopember Institute of Technology, Surabaya, Indonesia) ( ${ }^{3}$ Government Affairs and Administration, Universitas Muhammadiyah Yogyakarta, Indonesia)

Towards an Integration of Immigration and Customs Agency in Indonesia: A Step-by-Step Process

\section{7 - $144 \quad$ Ridwan Arifin' ${ }^{1}$, Intan Nurkumalawati ${ }^{1}$}

(1 Diploma Program of Immigration Administration, Polytechnic of Immigration, Indonesia) 


\title{
Collaborative Urban Governance Model in Environmental Management of Industrial Area
}

\author{
Tri Sulistyaningsih ${ }^{1 *}$, Saiman ${ }^{1}$, Nofianda Fatimah Azzahra ${ }^{1}$, Nanda Adityawan², \\ Mohammad Jafar Loilatu ${ }^{3}$ \\ ${ }^{1}$ Department of Government Studies, Universitas Muhammadiyah Malang Indonesia \\ ${ }^{2}$ Civil Engineering, Sepuluh Nopember Institute of Technology, Surabaya, Indonesia \\ ${ }^{3}$ Government Affairs and Administration, Universitas Muhammadiyah Yogyakarta, Indonesia \\ *Email Correspondence: sulis226@gmail.com
}

\begin{abstract}
This paper's purpose for this study is to provide an overview related to the partnership or the cooperation between the government and the private sector, specifically the manager of the industry and the community in the environmental management of the industrial area in Gresik and Sidoarjo Regency. This research used a qualitative approach to analyze the data, interviews, documentation, and questionnaires. This study revealed that the environment's management in a sustainable manner should be supported by stakeholders, the government, the community, and the private sectors. Also, this research attends to instill a sense of environmental concern in the entire party. Collaborative urban governance sustainability not be separated from the leader's success in embracing the related parties and using existing industry resources. The stakeholder determines the success of managing the industrial area in the Gresik and Sidoarjo Regency, government, public, and private parties through a Collaborative Urban Governance model.
\end{abstract}

Keywords: Industrial area, Government, Environmental Management

\begin{abstract}
ABSTRAK
Tujuan penelitian ini adalah untuk memberikan gambaran kemitraan atau kerjasama antara pemerintah dengan pihak swasta, khususnya pengelola industri dan masyarakat dalam pengelolaan lingkungan kawasan industri di Kabupaten Gresik dan Sidoarjo. Penelitian ini menggunakan pendekatan kualitatif untuk menganalisis data, wawancara, dokumentasi, dan angket. Studi ini mengungkapkan bahwa pengelolaan lingkungan secara berkelanjutan harus didukung oleh pemangku kepentingan, pemerintah, masyarakat, dan pihak swasta. Selain itu, penelitian ini hadir untuk menanamkan rasa kepedulian lingkungan pada seluruh pihak. Keberlanjutan Collaborative Urban Governance tidak lepas dari keberhasilan pimpinan dalam merangkul pihak terkait dan menggunakan sumber daya industri yang ada. Keberhasilan pengelolaan kawasan industri di Kabupaten Gresik dan Sidoarjo ditentukan oleh keterlibatan pemangku kepentingan, pemerintah, publik, dan swasta melalui model Collaborative Urban Governance.
\end{abstract}

Kata Kunci: Kawasan Industri, Pemerintah, Pengelolaan Lingkungan

Citation: Sulistyaningsih, T., Saiman, Azzahra, N. F., Adityawan, N., \& Loilatu, M. J. (2021). Collaborative Urban Governance Model in Environmental Management of Industrial Area. Journal of Government and Civil Society, 5(1), 107-126. 


\section{INTRODUCTION}

The environmental management of the industrial area in East Java is still partial and less sustainable. Many problems still occur, such as economic inequality, technology, environmental degradation, land conversion, social inequality, and the environment's institutional management's ineffectiveness. Government regulation No 24 of 2009, which was subsequently replaced by government regulation No 142 of 2015, regulates that Indonesia's manufacturing industry activities should be located in the industrial area, yet to be implemented optimally. Environmental management in the industrial area has not been able to occur in a harmonious and sustainable (Wikaningrum, 2016).

Therefore, collaborative urban governance is essential to accomplish. It is to achieve the purpose of the industrial environments that are harmonious and sustainable. The involvement of government stakeholders, the industry manager, and the community collaboratively is a necessity. Thus collaborative urban governance model involves the various stakeholders (Bartocci \& Picciaia, 2020; Jean et al., 2018; McDonald \& Young, 2012; Wang et al., 2019)in the industrial area's environmental management. Environmental management in the industrial area is also related to the way to manage the waste generated. The industrial area accounted for more waste that than the non-industrial area. The following table will overview the magnitude of waste per day, solid waste in Asia.

Table 1. Solid Waste in Asia 2020

\begin{tabular}{ccc}
\hline Countries & $\begin{array}{c}\text { Waste Generated } \\
(\mathrm{Kg} / \text { Day })\end{array}$ & $\begin{array}{c}\text { Annual MSW Generation } \\
\text { (in Ton) }\end{array}$ \\
\hline Brunei Darussalam & 1,4 & 210,480 \\
Malaysia & 1,17 & $1,284,000$ \\
Myanmar & 0,53 & 841,508 \\
Philippines & 0,69 & $14,660,000$ \\
Indonesia & 0,70 & $64,000,000$ \\
Singapore & 3,736 & $7,514,500$ \\
Thailand & 1,05 & $26,770,000$ \\
Vietnam & 0,84 & $22,020,000$ \\
\hline
\end{tabular}

Source: (UNEP, 2020)

Based on table 1, Indonesia generates $0.70 \mathrm{~kg} /$ person/day of solid waste. Based on this data, every day in 2020, Indonesia produces 64,000,000tons/day. On average, Indonesia generates 64 million tons/day of solid waste only. 


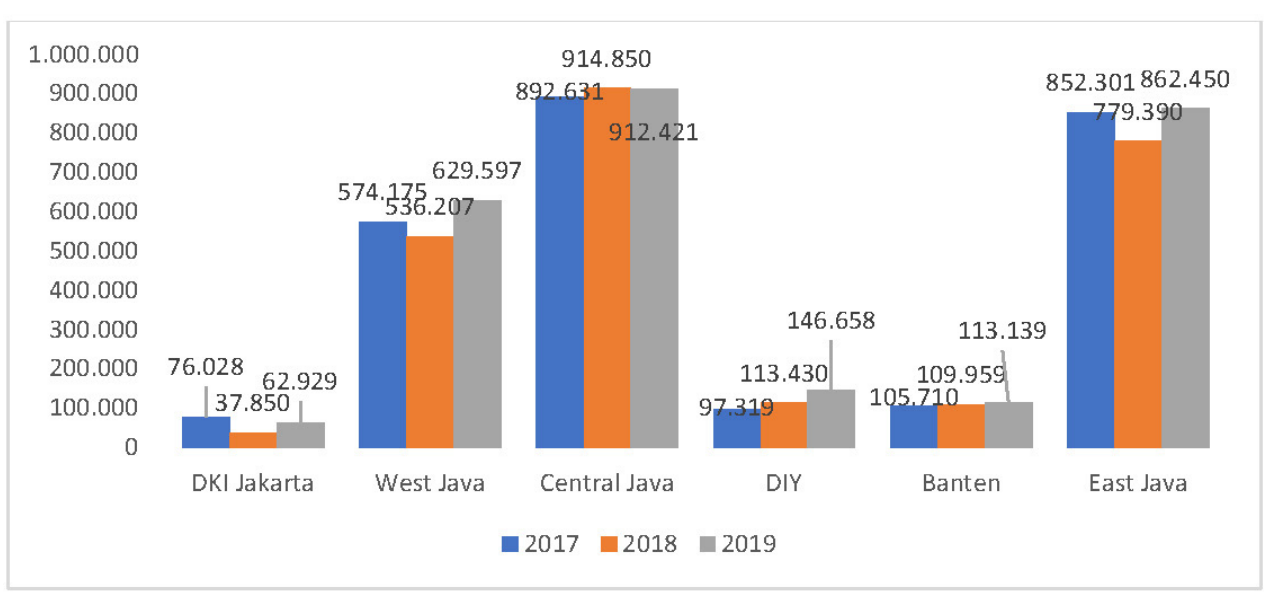

Figure 1. The total of the industry at Java in 2017-2019

Source: (Badan Pusat Statistik, 2020)

According to Figure 1, East Java province has now been one of the second largest manufacturing areas in Java. It cannot be disputed that industrial area production contributes significantly to economic growth - one of the industrial areas' developments stalled in the ring Gresik industrial area and Sidoarjo industrial area. Furthermore, there is a detrimental effect of economic development on the environment. It is evidenced by disruptions in sanitation and numerous environmental contaminants, which become the primary impact of industrial development. It harms the people who live in the immediate environment, such as water and soil contamination.

Industrial waste, such as non-organic waste and chemical substances residual from the production process, causes water and soil pollution. In some industry types, air pollution involves production processes that produce smoke that rises almost every time the factory operates throughout the day, 24 hours non-stop. This smoke naturally contains most substances that dangerous when inhaled. Besides the smoke, the dust produced can lead to contamination of clean air.

Table 2. The National Environmental Quality Index 2015-202

\begin{tabular}{cccccc}
\hline Years & Target & Attainment & Description & East Java & Description \\
\hline 2015 & 63 & 68,23 & Moderate & 62,67 & Moderate \\
2016 & 63,50 & 65.23 & Moderate & 58,98 & Moderate \\
2017 & 64 & 66,46 & Moderate & 57,46 & Moderate \\
2018 & 65 & 65,14 & Moderate & 67,08 & Moderate \\
2019 & 66,5 & 66,55 & Moderate & 60,25 & Moderate \\
2020 & 68,71 & 70,27 & Good & 67,07 & Moderate \\
\hline
\end{tabular}

Source: (Kementrian Lingkungan Hidup dan Kehutanan, 2018, 2019, 2020) 
Table 2 Environmental Quality Index is utilized as an information or measurement tool in making policy related to the management and protection of the environment. (Kementerian Lingkungan Hidup, 2015). Table 1 shows that from 2015 to 2020, the environmental quality, both nationally and in East Java, continues to decrease. Moreover, the quality of East Java's environment since 2016 has been in a moderate status. The environment's quality decreases because of a load of liquid hazardous and toxic waste from the industry (Kementerian Lingkungan Hidup, 2015), From 2018 to 2020, it increased to 67.07, but it is still in the moderate category (Kementrian Lingkungan Hidup dan Kehutanan, 2020).

However, the industry's activity can not be separated from the waste generated from the industries' production process because they produce 24 hours non-stop. There are various types of waste generated. The following data is concerning the various kinds of waste generated on a national scale.

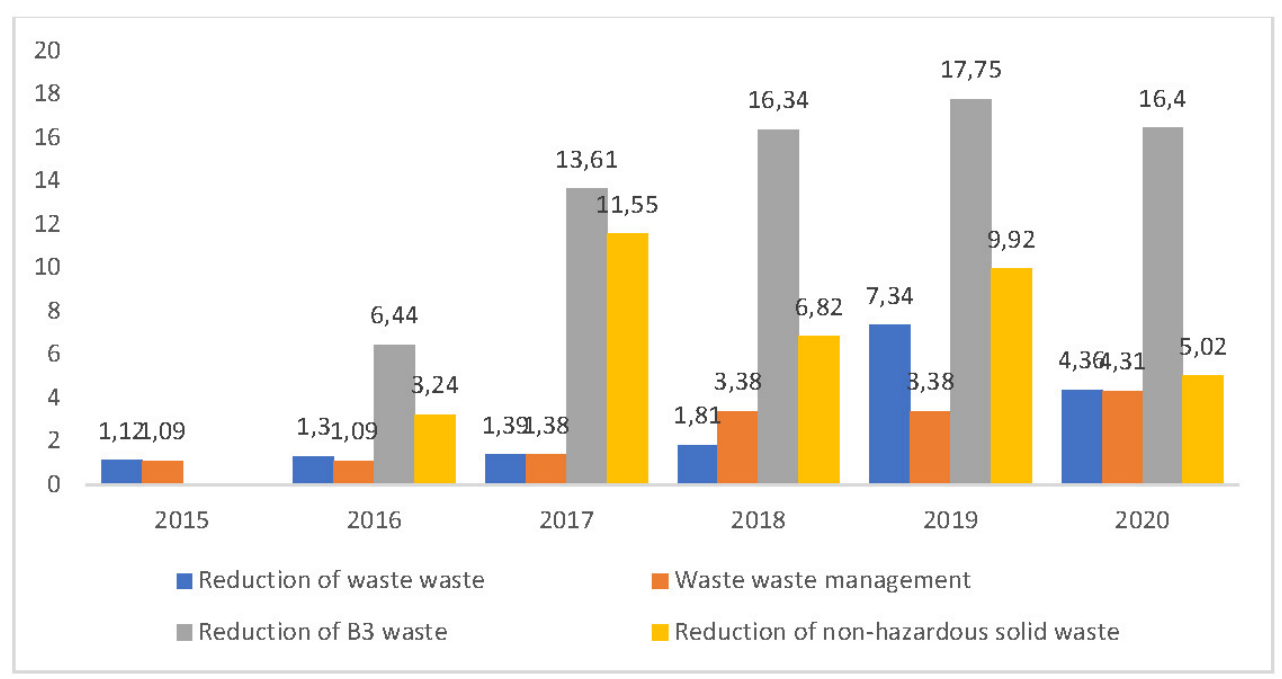

Figure 2. Indonesia waste in $2015-2020$ Sources: (Kementrian Lingkungan Hidup dan Kehutanan, 2020)

Based on figure 2 above, hazardous and toxic waste has been recognized as the most significant contributor to waste. However, hazardous and toxic waste has special treatment and has to go through some process before being thrown away. This B3 waste type is a waste that harms the environment if not explicitly handled. Therefore, the industry's development must be well adjusted with environmental management around the industrial area. Based on this graph, there are efforts to overcome environmental problems by managing waste and reducing it with management efforts.

Since the environmental problems that will occur after the development of the industrial area may affect the private sector's business activity performance, the government cannot 
work separately but the necessity of the private sector and the community's support in its environmental management. It will also harm people if environmental problems later impact the community's lives around the industrial area.

Previous researchers on environmental management in the industrial area, Purnaweni (2014) explain that the management of the environment in an industrial area is hand in hand and adjusts with its geographical location characteristics to protect and maintain a region. On the other hand, a policy caused controversy with the local community in the Industrial Area of Kendeng Utara, Central Java, located in a row of karst mountains. The community considers the policy a strategy that is more pro investors in harnessing the wealth of nature in the Karst area. The Karst Area is a protected area that needs to be maintained preservation of the environment. Furthermore, the study about environmental management in the industrial area was measured using environmental management approach.

Temmy Wikanungrum, Bambang Pramudya, (2015) explains that environmental management in the industrial area of Jababeka Bekasi from 2008-2014 was to show sustainable management and is still not following the criteria of ecological, economic, and social that have been appropriately outlined by the Ministry of Environment and Forestr. However, based on the institution's sustainability aspect in the industrial area of Jababeka Bekasi, it has already proved sustainability by the presence of ISO certification for environmental management systems, quality, and health and safety

Fatah Sulaiman, Asep Saifuddin, Rizal Syarif(2008)revealed that it needs a strategy to manage the industrial area in Cilegon to get towards Eco-Industrial Park with the system's construction to place integrated industrial waste. Also, it requires industrial symbiosis to the surrounding and the CSR application that right on target. The government also has a significant role in developing the industry to become Eco-Industrial Park. Later, investors follow and manage the company and involve the community, academics, and environmental NGOs.

According to recent research Migdar (2019), the Karawang area occurs a significant industrial development. Thus, it needs local authorities' strategy to suppress the negative impact of the industry's construction. Creating a synergistic relationship between government, companies, and community is necessary to control industrial development's negative impact in the region.

Alrasyid (2016), in his research, explains that in working the process of Environmental Strategic Management, the industry needs leaders who are truly capable of implementing supportive policies for environmental management and control. So far, what has happened is that the green industrial area has not yet been realized because there are still no supporting regulations in terms of environmental management and control. It is also not yet integrated between the government and the company and is still not sustained by 
supporting infrastructure. Nevertheless, it is because community-based partnerships have not been maximally implemented.

Amelia Novita(2018) mentions the need for collaborative governance to maintain and improve the environmental security conditions. If only imposed on one actor, for example, supposing by only the government, it will not produce maximum results and unsustainable development goal. Thus, it requires a Collaborative Governance approach between the government, community, and stakeholders in a balanced way to realize sustainable environmental security. Working together and present their respective roles.

Indeed, this research differs from some previous studies because this will describe a Collaborative Urban Governance model in managing the industrial area in Gersik and Sidoarjo. Base on the research question, it is interesting to investigate a collaborative urban governance model in managing East Java's environment, particularly in the Gresik and Sidoarjo Regency. There are developing a variety of new industries in the Gresik and Sidoarjo regency. The establishment of an industrial area following government regulation No. 35 of 1989 aims to provide convenience in providing electricity, water, firefighting units (Alrasyid, 2016)

\section{LITERATURE REVIEW AND RELATED STUDIES}

Epistemologically, the word collaborative or collaboration means working together. In the 19th century, in industrialization, the application of the word collaboration started to develop. The organization at that time was very complex. Divisions within the organization began to be made to distribute work tasks for the organization's workers (Chilima et al., 2013; Imperial, 2005a). Philosophically of collaboration are various parties' efforts to accomplish the corresponding goal(Imperial, 2005b). According to Margerum(2008), collaboration is an effort to unify the various parties to achieve the same goal. Collaboration requires a wide range of actors, individuals, and organizations to perform tasks to achieve common goals together(Amelia Novita, 2018; Bua et al., 2018; Duan et al., 2020)

The meaning of governance can be interpreted descriptively or from the viewpoint (Arrozaaq, 2016). Descriptively, governance or government is a phenomenon that occurs both in developed and developing countries as a form of government implementation. In government, there are three important and related actors: the government, the private sector, and the community (Sajwani \& Nielsen, 2019), the three actors involved in the formation or development of a region. Emerson et al.(2009)stated that collaborative governance is a form of a process in the composition and public policy-making involving government institutions, community, and the private sector is packed in one common goal (Muzwardi, 2018).

Likewise, collaborative urban governance should be packed in one common goal even though the actors involved in such cooperation having personal importance but must be 
packed in one common goal(Ferreira et al., 2020). It is intended to minimize the conflicts between actors with a different purpose because it will inhibit collaborative governance.

The conclusion that can be drawn is that collaborative urban governance is commonly referred to as collaborative governance (Chris Ansell \& Gash, 2018; Bodin, 2017), is a new governance strategy that makes various policymakers gather in the same forum to create a consensus or common problems' solving (Chris Ansell \& Gash, 2008). More for collaborative urban governance as a management innovation of government where one or several public institutions involved actors non-governmental according to government policy and regulations (da Cruz et al., 2019; Wikaningrum et al., 2015)in the process of making a formal collective policy-oriented on the common interests and aims to implement public policies to manage programs or public assets (Ahluwalia, 2019; Chris Ansell \& Gash, 2008; Cheng \& Li, 2019; da Cruz et al., 2019; Wikaningrum et al., 2015).

The practice of collaborative urban governance is also concerned with the necessity of networking (networks) conducted by the government with various actors, such as the public and private sectors. It is necessary to have a network or collaborate with various stakeholders to produce maximum results (McDonald \& Young, 2012). Indeed, every actor's collaboration must have limitations or restrictions in dealing with each of the problems. These limitations are so that there is no gap or domination in a collaboration. Networking/networks are also essential to exchange resources owned by the actors or institutions involved. To exchange resources in running the collaborative urban governance, the actors must hold principles or have a sense of "mutual dependence and trust (Newig et al., 2018).

In general, collaborative governance appears due to the reason of the complexity and interdependency of government agencies. There are still many complex conflicts that are muted because of the group's interests and needed a much more efficient way to gain political legitimacy. Chris Ansell \& Gash (2008) mentioned that collaborative governance is necessary, either stressed the importance of collaborative governance for many factors, including the failure of policy application in the field, the weakness of some groups due to the distribution of power that becomes an obstruction in decision-making, and the mobilization of the interests of the group and the last is the high cost and politicization of regulation (Chris Ansell \& Gash, 2008; Christopher Ansell et al., 2020; Weir et al., 2009). 


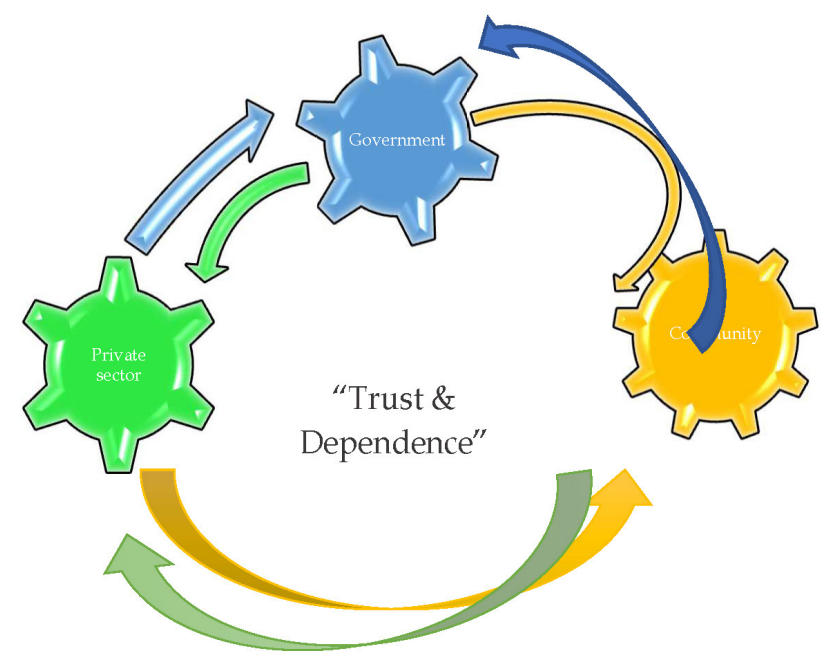

Figure 3. The Principle of Collaborative Urban Governance by Ansell and Gash Sources: (Chris Ansell \& Gash, 2008, 2018)

This collaborative governance will assist the government's performance, especially on public issues, because networking with non-government actors such as the public community and the private sector will provide many solutions to have less possibility of failure implementation. Indeed, integrating the various interests and purposes of each actor into one common goal by depending on each other to exchange the resources that each actor takes

The involvement of the community and private sector with the government is an action that is necessary to create sustainable development, including issues in an urban concern between man and environment (Durant, R. F., Fiorino, D. J., dan O'Leary, 2004). Because public community and the private sector will also be affected by the government's policy, developing collaborative governance involving the community and the private sector is the right partnership so that community and the private sector can also be voiced or represent the interests of their group (Bingham, 2006). Hence their voice will be taken into consideration/input and generating cooperation which has a sustainable outcome.

Collaborative governance is characterized or initiated with the dialogue and deliberation that serves to exchange information and opinions between the government, community, and the private sector to produce an agreement of a common goal(Bingham, 2006). Collaborative urban governance is considered to be more able to create a fair solution/ policy related to urban areas' environmental problems (Durant, R. F., Fiorino, D. J., dan O'Leary, 2004). By running collaborative urban governance, the government will also consider the environmental impact of the community's welfare and the private sector. Therefore, between the government, community, and the private sector, they will cooperate in finding a solution together in a balanced way without being dominating. 


\section{Theory of Collaborative Urban Governance}

The process of collaboration between the government and actors of the nongovernmental required several stages. Collaborative governance is the role that provides space for each actor to formulate and adopt policies; such collaboration forms are crosslevel (de Oliveira Faria \& Magrini, 2016). This approach follows that actors from different levels are needed to be involved (Chris Ansell \& Gash, 2008) to maintain environmental security (Amelia Novita, 2018). This researcher used the theory of Ansell and Gash.

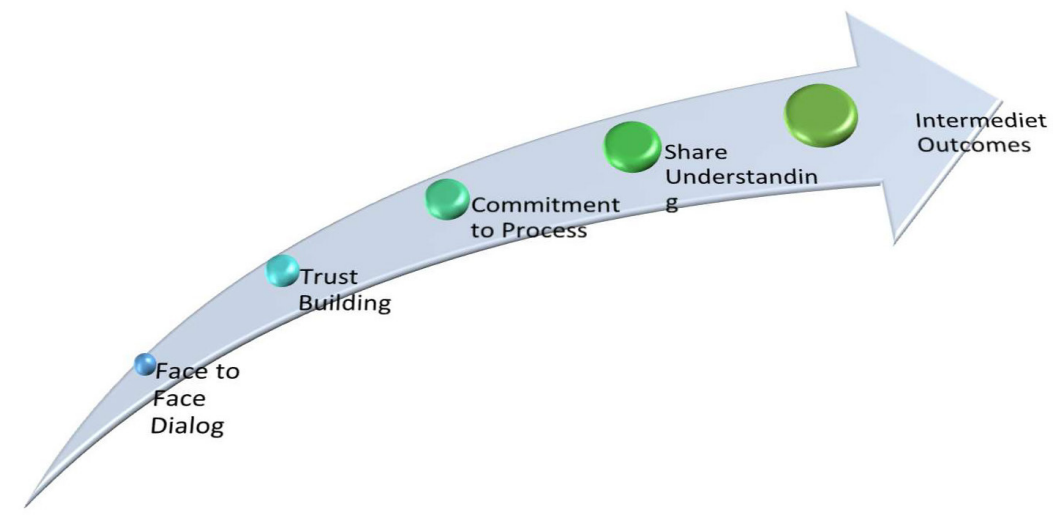

Figure 4. The Stages of Collaborative Urban Governance

1. Face to Face Dialog

The beginning of the Collaborative Governance process starts with doing dialogue directly with the related parties. In environmental management in the Kawasan Industri Gresik (KIG) and Brebek Industri, the government was at least trying to communicate with the representatives of stakeholders and community about the identification of opportunities, obstacles, advantages, and disadvantages that all parties would experience, also the environment if the industrial area is growing.

2. Trust Building

Building good communication was one of the supporting factors for a collaborative process. The collaboration was not just an effort of negotiations among stakeholders, but rather the effort to build trust. This was intended so that the related parties did not prioritize their interest and made them aware that their interests could be facilitated with collaboration.

3. Commitment to Process

Commitment certainly has an essential role in the process of collaboration. A commitment was a reference to engage or participate in Collaborative Urban Governance. A strong commitment from the government and stakeholders was necessary to prevent a collaboration process's negative impact. 
4. Share Understanding

At the same point in collaboration, the stakeholders involved should understand what they can achieve through collaboration. Sharing of understanding provides clarity of input and output from a collaboration.

\section{Intimate Outcomes}

The continuation of the process of collaboration materialized in the form of output or the actual output. Intermediate outcomes will appear if the objectives that may provide benefits from the collaboration were relatively concrete were possible to happen.

\section{RESEARCH METHOD}

This research was conducted through a qualitative approach (Hammarberg et al., 2016; Mohajan, 2018). Data collection was achieved through the questionnaire to find out systematically how the collaboration between the related parties and also numerous interviews with government agencies who have an essential role in the environmental management of the industry represented by the Department of the Environment, Department of Public Works, and Spatial Planning as well as representatives of the community in the Gresik and Sidoarjo Regency. After the data was collected, the data analysis was conducted through interactive methods (Holtrop et al., 2018). Thus, it can be seen how the cooperation between the government and the related parties was going, and any problems that arise and made the collaboration of the environmental management of the industrial area in Gresik and Sidoarjo Regency was still not optimal.

\section{FINDINGS AND DISCUSSION}

The construction industry influenced economic success. Industrial development in East Java, particularly Gresik and Sidoarjo Regency, was very rapid. It is shown by the emergence of various industrial estates spread across the two regions. Although the industry's development positively impacted the fieldwork, it cannot be denied that the industry's development also brought adverse effects that were environmental damage. There is a cooperation or collaboration between the government, community, and stakeholders to prevent and mitigate the environmental damage that will happen or already happened.

The industrial area in Gresik regency has approximately 3.577,25 $\mathrm{Ha}$, while particularly for Kawasan Industri Gresik (KIG) has an area of $140 \mathrm{Ha}$ and $100 \%$ of the land used as industrial in the Kawasan Industri Gresik (KIG). On the other hand, the industrial area in the Sidoarjo Regency has $389 \mathrm{Ha}$, and specifically, IndustriBerbekSidoarjo has an area of 87 ha, and $100 \%$ of the land was already used as industrial in Kawasan IndustriBebek. 


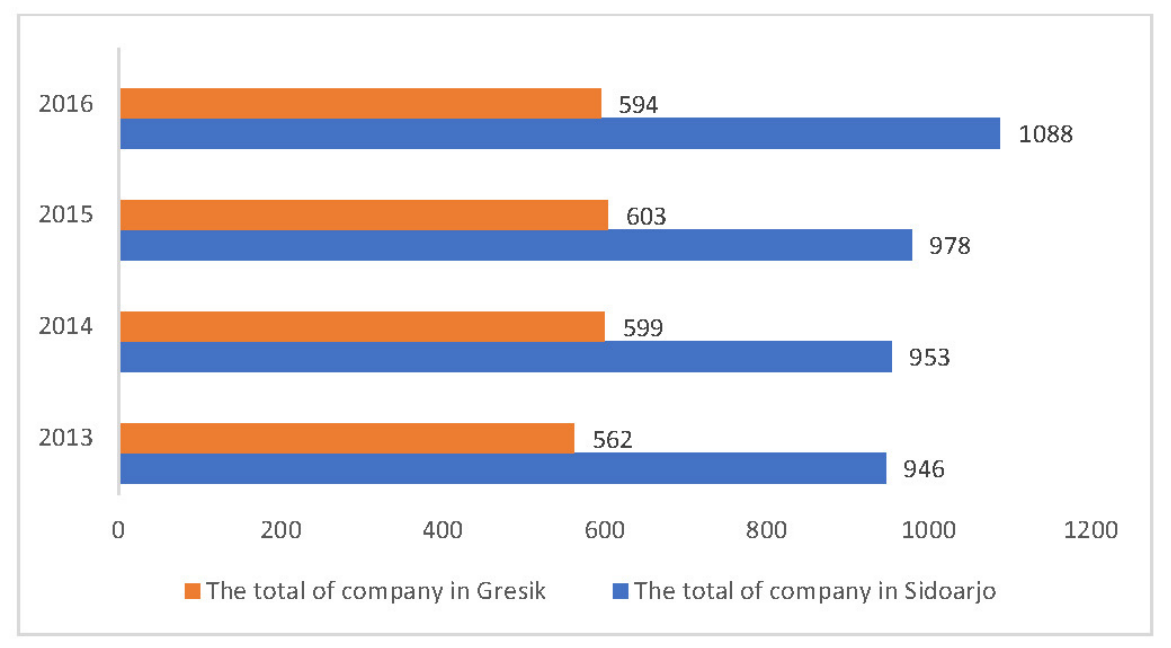

Figure 5. The total of the company in Sidoarjo and Gresik Source: (Badan Pusat Statistik West Java. 2020)

Figure 5 above showed that the number of industries in the industrial area, especially in the Gresik and Sidoarjo Regency, increased from year to year. The increase in the number of industries would also affect the management of environment-related problems, including industrial waste. The more emerging industries, the more environmental impacts would be generated from these industries' production processes. To optimize the management of the industrial area's environment, it needs government, community, or stakeholders to pay attention to environmental issues that occur in the industrial area.

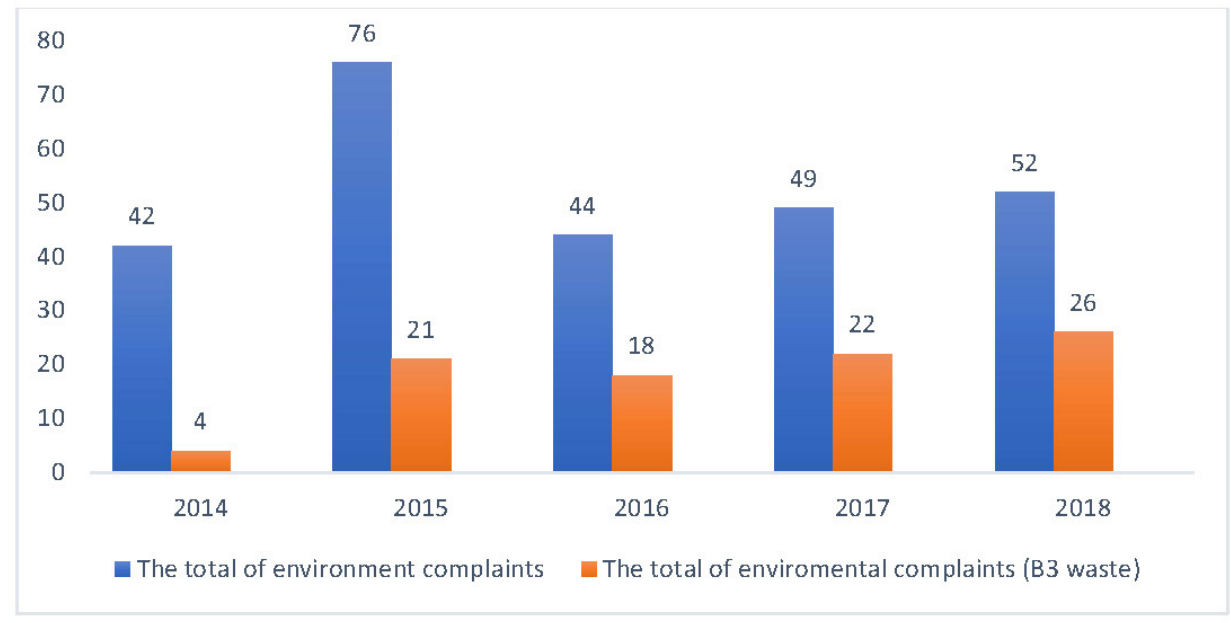

Figure 6. The total of environmental complaints Source: (Dinas Lingkungan Hidup West Java, 2018) 
Figure6 above shows that environmental problems have increased from 2014-2015. However, it is decreasing in 2016 and slightly increasing again in 2017-2018. Regarding the environmental problems of B3 waste, it has increased from 2014-2018. The government could not work alone and required cooperation with various community and stakeholders concerning environmental problems.

This research was conducted to determine the government's performance in industrial areas' environmental management, whether it has been running optimally or not, by the Collaborative Governance method with industry and the community. Furthermore, discussion regarding collaborative governance in the industrial area's environmental management institution was broken down into three aspects of the main study, 1) Identification of face-to-face process in the implementation of the environmental management industrial area, 2) Identification of the negotiation process in the implementation of the environmental management of the industrial area, and 3) Identification the process of consensus in the system of institutional.

\section{The Identification Office-to-Face Process in The Implementation of Management of Industrial Area Program}

The face-to-face process between local government and business actors has occurred in the form of face-to-face. In every industrial area's environmental management process, Gresik and Sidoarjo regency's government tries to conduct a dialogue directly with the parties involved. Based on the results of interviews with staff of environment institutions, it can be concluded that both regency in the dialogue face-to-face with local government and business actors often discussed problems that occur in the industry (Geng \& Côté, 2003). It took an important role of business actors and community so that the government could do the mapping problems in the field. Based on the interview results, the problems faced by government and business actors were the lack of facilities and a few supervisors who elucidated the importance of environmental management of the industrial area and the management of wastewater treatment. Dynamic institutions can encourage institutions and society's role so that the government can work together to solve environmental problems (Emerson et al., 2009).

In implementing the industrial area program in Sidoarjo and Gresik Regency, the local government conducted the socialization and technical guidance directed to business actors to understand, implement, and adhere to industrial waste policies before disposal. The government also engaged in dialogue with the community, especially those whose settlements were near the industrial area. Therefore, the community understands how the procedures for monitoring and complaints arise in their environment due to the industry's waste arrangement. 
The process of face-to-face dialogue between local government, business actors, and community is also implemented at the time of the installation, in which the location was nearby between the residential area and the industrial area. The Wastewater treatment plant has been done inside the company as a form of awareness in the waste management industry. The community's function here was as a superintendent of the industrial area's environmental management to keep them running correctly and not pollute the environment. The government itself had a function as a recipient of the community's aspirations and be an overseer for the industry's implementation in the regency of Gresik and Sidoarjo through reports of environmental problems of the industry regularly.

The explanation above showed that the cooperation between the government, businesses, and community has been running well but is not yet fully optimal because some business actors lack transparency in managing their waste disposal.

\section{The Negotiation Process Identification in The Implementation of The Management of The Industrial Area}

The negotiation phase was the bargaining process among stakeholders to define a common goal to achieve a win-win solution. It means that all parties were benefited or at least found an agreement together but not to harm each other. The consensus-oriented basis of collaborative governance dramatically reduces stakeholders' risks (Chris Ansell \& Gash, 2018).

The negotiation process between the government, business actors, and community going in the dialog face-to-face. So both processes were carried out simultaneously. Negotiations happened after the government was mapping the problems and determining industrial areas' environmental management policies. The negotiations in this process were taken more formally because the topic discussed was related to strategic matters. It linked industrial area management to the industrial area program's management through cooperation between government, business actors, and the community. One of the programs launched by the government was the, The Wastewater treatment plant installation has do particularly management industrial area.

Negotiations concerning environmental management in the industrial area in Gresik and Sidoarjo Regency itself involved several government institutions, business actors, and the community. The form of negotiations between the government and the business actors associated with environmental management policy in the industry, the management of hazardous and toxic waste (B3 in Indonesian abbreviation), the provision of the wastewater treatment plant in the industrial area, and the coordination in the AMDAL preparation.

Negotiations were conducted with more free media and did not bound to space and time. This negotiation process occurs when a matter or problem is found regarding the 
industrial estate wastewater treatment program of an industrial area with other problems that are not too big. However, negotiations conducted by local government and business actors sometimes did not involve the community (Parés et al., 2017; Pidji Astuti, Nanik Setyowati, 2017). While the community also felt the industry's impact, they did not know how the industrial area's environmental management was running. Also, some of the companies' wastewater treatment in the industry area was located in the inaccessible area. It causes the function of the community as the overseer did not go well. Therefore, the negotiation process that should be characteristic of bottom-up tends to be topdown(Koontz \& Thomas, 2018).

Healey(2003) the negotiations between the parties involved in a program of public policies strongly determine the direction of change that was expected to impact the implementation of the policy process positively and somewhat more to achieve the welfare of the people more broadly. The policy process should be impacting on other factors, on the others thing the policy should be assessed across others organization to the result between them (Benson et al., 2013)

\section{The Process of Consensus in The Institutional System}

The consensus in the institutional system of environmental management of the industrial area was the way out of its problems. In the process of environmental management of the industrial area, the government plays a role as the maker and implementer of policy management of the industry, business actors implement the policy and management of the environment, and the community played a role as a supervisor of the management of the industrial area implementation. According to ( $\mathrm{O}$ et al., 2018), the risks arising from industrial activities make the environment worse. Therefore every problem is solved together, and the decision is made by the parties involved. In that process, the government will listen to any feedback and suggestions to be discussed later (Brands, 2005; Woldesenbet, 2020). In the application, they determined an agreement was not wholly pure because the community only played a role as a controller of environmental management implementation without knowing how to plan and implement the wastewater treatment.

The community is not involved directly in the planning of the implementation of the wastewater treatment, because the industry has a system of its own in the planning and implementation of the wastewater treatment. However, the community here is only involved in the relation of the industry's supervision and given the facilities for the transport of garbage to not cause environmental pollution in the settlements.

The community's unawareness of the industry's environmental management, particularly in the management of the wastewater treatment, was one of the forms of dominance process in the cooperation between the government and third parties. Hence, 
the community considers that the program launched by the government was just a formality. In comparison, the consensus itself would produce good results if the actors know the importance of communication. Without these conditions, the dominance would continue to occur, which causes the community to feel hesitant to see their own needs due to the minimal effort to reveal the dependency between actors' interests and the ongoing domination practice.

Based on the existing problems, the researchers tried to provide the institutional model optimal in the industrial area's environmental management that involved all parties' cooperation. The cooperation pattern between the involved actors showed that they actively did the same work, but such cooperation did not fully touch the other actors. To deal with such circumstances, be made to the institutional model based on Collaborative Governance, as shown below.

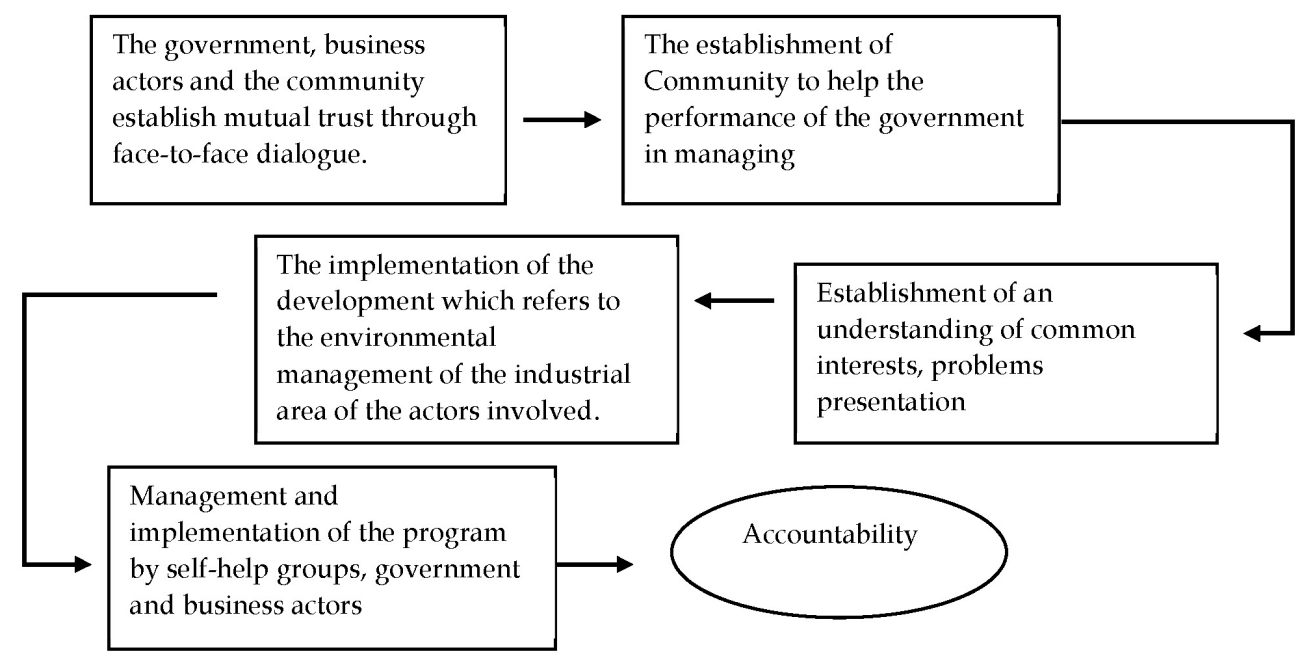

Figure 7. Institution Collaborative Model

A Model of institutional strengthening collaborative has an essential role in building community involvement. This model can strengthen the networking system and the flow of information. Also, it can clarify the role of each stakeholder as well as accountability. The model above is a flow of identification, negotiation, and the policy-making process through the collaborative network and collaborative governance; Ansel and Gash have described how to solve problems in the environment. This study confirms several findings and models that have been developed in line with the views (Chris Ansell \& Gash, 2008; Armstrong \& Jackson-Smith, 2017; Bartocci \& Picciaia, 2020; Brink \& Wamsler, 2018; Ebrahim, 2004; Imperial, 2005a), and the type of collaborative environmental management(Margerum, 2008), based on the context and governance of organizations and governments ((Imperial, 2005b). 


\section{CONCLUSION}

Although the implementation of Collaborative Governance in the industry's environmental management can be running well, community participation and institutional performance in Gresik and Sidoarjo Regency are still not optimal. It needs institutional strengthening through cooperation collaborative between the actors involved so that the program will work effectively. In institutional strengthening, the efforts to clarify community involvement from planning to the program's evaluation are the primary requirement. Local governments need to create guidelines for implementing the program, starting from the collective agreement process until a system of accountability based on each of the stakeholders' roles. Lastly, the community's learning process on the program's management ensures the program's sustainability should also continue to be escorted until realizing the ideal management system.

\section{REFERENCES}

Ahluwalia, I. J. (2019). Urban governance in India. Journal of Urban Affairs, 41(1), 83-102. https:/ / doi.org/10.1080/07352166.2016.1271614

Alrasyid, M. H. (2016). Environmental Strategic Management Untuk Kawasan Industri Hijau. Journal of Environmental Education and Management, 1(1).

Amelia Novita, A. (2018). Collaborative Governance dan Pengelolaan Lingkungan Hidup di Kawasan Pertambangan. Jurnal Ilmiah Administrasi Publik, 4(1), 27-35. https:// doi.org/10.21776/ub.jiap.2019.004.01.4

Ansell, Chris, \& Gash, A. (2008). Collaborative governance in theory and practice. Journal of Public Administration Research and Theory, 18(4), 543-571. https://doi.org/10.1093/ jopart/mum032

Ansell, Chris, \& Gash, A. (2018). Collaborative platforms as a governance strategy. Journal of Public Administration Research and Theory, 28(1), 16-32. https://doi.org/10.1093/ jopart/mux030

Ansell, Christopher, Doberstein, C., Henderson, H., Siddiki, S., \& 't Hart, P. (2020). Understanding inclusion in collaborative governance: a mixed methods approach. Policy and Society, 00(00), 1-22. https://doi.org/10.1080/14494035.2020.1785726

Armstrong, A., \& Jackson-Smith, D. (2017). Connections and Collaborations of Local Water Management Organizations of Utah. Society and Natural Resources, 30(11), $1343-$ 1357. https:// doi.org/10.1080/08941920.2017.1347972

Arrozaaq, D. L. C. (2016). Collaborattive Governance (Studi Tentang Kolaborasi Antar Stakeholders Dalam Pengembangan Kawasan Minapolitan di Kabupaten Sidoarjo). Kebijakan Dan Manajemen Publik, 3, 1-13. http:// repository.unair.ac.id/67685/

Badan Pusat Statistik. (2020). Jumlah Perusahaan Menurut Provinsi. Https:// Www.Bps.Go.Id/Indicator/170/440/1/Jumlah-Perusahaan-Menurut-Provinsi.Html. Badan Pusat Statistik Jawa Timur. (n.d.). Badan Pusat Statistik Jawa Timur. BPS JATIM. 
Bartocci, L., \& Picciaia, F. (2020). Looking for new paths to realize cross-sector collaboration for urban regeneration: The case of castel del giudice (Italy). Sustainability (Switzerland), 12(1), 1-15. https:// doi.org/10.3390/su12010292

Benson, D., Jordan, A., Cook, H., \& Smith, L. (2013). Collaborative environmental governance: Are watershed partnerships swimming or are they sinking? Land Use Policy, 30(1), 748-757. https://doi.org/10.1016/j.landusepol.2012.05.016

Bingham, L. B. (2006). The new urban governance: Processes for engaging citizens and stakeholders. Review of Policy Research, 23(4), 815-826. https://doi.org/10.1111/j.15411338.2006.00234.x

Bodin, Ö. (2017). Collaborative environmental governance: Achieving collective action in social-ecological systems. Science, 357(6352). https://doi.org/10.1126/ science.aan1114

Brands, O. M. (2005). At a Watershed: Ecological Governance and Sustainable Water Management in Canda (pp. 1-15).

Brink, E., \& Wamsler, C. (2018). Collaborative Governance for Climate Change Adaptation: Mapping citizen-municipality interactions. Environmental Policy and Governance, 28(2), 82-97. https://doi.org/10.1002/eet.1795

Bua, A., Davies, J., Blanco, I., Chorianopoulos, I., Cortina-Oriol, M., Feandeiro, A., Gaynor, N., Griggs, S., Howarth, D., \& Salazar, Y. (2018). The urban governance of austerity in Europe. The Routledge Handbook of International Local Government, Davies 2011, 280295. https:// doi.org/10.4324/9781315306278-19

Cheng, R., \& Li, W. (2019). Evaluating environmental sustainability of an urban industrial plan under the three-line environmental governance policy in China. Journal of Environmental Management, 251(September), 109545. https://doi.org/10.1016/ j.jenvman.2019.109545

Chilima, J. S., Gunn, J. A. E., Noble, B. F., \& Patrick, R. J. (2013). Institutional considerations in watershed cumulative effects assessment and management. Impact Assessment and Project Appraisal, 31(1), 74-84. https:// doi.org/10.1080/14615517.2012.760227

da Cruz, N. F., Rode, P., \& McQuarrie, M. (2019). New urban governance: A review of current themes and future priorities. Journal of Urban Affairs, 41(1), 1-19. https:/ / doi.org/10.1080/07352166.2018.1499416

de Oliveira Faria, C., \& Magrini, A. (2016). Biodiversity Governance from a Cross-Level and Cross-Scale Perspective: The case of the Atlantic Forest biome in Brazil. Environmental Policy and Governance, 26(6), 468-481. https://doi.org/10.1002/eet.1728

Dinas Lingkungan Hidup Jatim. (2018). Informasi Kinerja Pengelolaan Lingkungan Hidup Daerah Provinsi Jatim Tahun 2017.

Duan, X., Dai, S., Yang, R., Duan, Z., \& Tang, Y. (2020). Environmental collaborative governance degree of government, corporation, and public. Sustainability (Switzerland), 12(3), 1-14. https://doi.org/10.3390/su12031138 
Durant, R. F., Fiorino, D. J., dan O'Leary, R. (2004). Environmental Governance Reconsidered: Challenges, Choices, and Opportunities. MA: MIT Press.

Ebrahim, A. (2004). Institutional preconditions to collaboration: Indian forest and irrigation policy in historical perspective. In Administration and Society (Vol. 36, Issue 2). https:/ / doi.org/10.1177/0095399704263481

Emerson, K., Gerlak, A. K., Barreteau, O., Buchholtz, M., Morrison, G., \& Promburon, P. (2009). A Framework to Assess Collaborative Governance: A New Look at Four Water Resource Management Cases.

Fatah Sulaiman, Asep Saifuddin, Rizal Syarif, A. F. Z. (2008). Strategi Pengelolaan Kawasan Industri Cilegon Menuju Eco Industrial Park. Journal of Regional and City Planning, 19(2).

Ferreira, V., Barreira, A. P., Loures, L., Antunes, D., \& Panagopoulos, T. (2020). Stakeholders' engagement on nature-based solutions: A systematic literature review. Sustainability (Switzerland), 12(2), 1-27. https://doi.org/10.3390/su12020640

Geng, Y., \& Côté, R. (2003). Environmental management systems at the industrial park level in China. Environmental Management, 31(6), 784-794. https://doi.org/10.1007/ s00267-002-2854-9

Hammarberg, K., Kirkman, M., \& De Lacey, S. (2016). Qualitative research methods: When to use them and how to judge them. Human Reproduction, 31(3), 498-501. https:/ /doi.org/10.1093/humrep/dev334

Healey, P. (2003). Collaborative planning in perspective. Planning Theory, 2(2), 101-123. https:// doi.org/10.1177/14730952030022002

Holtrop, J. S., Rabin, B. A., \& Glasgow, R. E. (2018). Qualitative approaches to use of the RE-AIM framework: Rationale and methods. BMC Health Services Research, 18(1), 110. https:/ / doi.org/10.1186/s12913-018-2938-8

Iaione, C. (2016). The CO-City: Sharing, Collaborating, Cooperating, and Commoning in the City. American Journal of Economics and Sociology, 75(2), 415-455.

Imperial, M. T. (2005a). Using collaboration as a governance strategy: Lessons from six watershed management programs. Administration and Society, 37(3), 281-320. https:/ / doi.org/10.1177/0095399705276111

Imperial, M. T. (2005b). Using collaboration as a governance strategy: Lessons from six watershed management programs. Administration and Society, 37(3), 281-320. https:/ / doi.org/10.1177/0095399705276111

Jean, S., Jean, S., Medema, W., Adamowski, J., Chew, C., \& Delaney, P. (2018). Serious games as a catalyst for boundary crossing, collaboration and knowledge co-creation in a watershed governance context. Journal of Environmental Management, June, 10101022. https://doi.org/10.1016/j.jenvman.2018.05.021

Kementerian Lingkungan Hidup. (2015). Indeks Kualitas Lingkungan Hidup Indonesia 2015. Jakarta: Kementerian Lingkungan Hidup Dan Kehutanan Republik Indonesia, 6. 
Kementrian Lingkungan Hidup dan Kehutanan. (2018). Indek Kualitas Lingkungan Hiudo. Pusat Data dan Informasi Kementrian Lingkungan Hidup dan Kehutanan republik Indonesia.

Kementrian Lingkungan Hidup dan Kehutanan. (2019). Statistik Kementria Lingkungan Hiudp dan kehutanan. Pusat Data dan Informasi Kementrian Lingkungan Hidup dan Kehutanan republik Indonesia.

Kementrian Lingkungan Hidup dan Kehutanan. (2020). Laporan Kinerja, Adaptasi di tengah Pandemic Mengawal Jaman Berubah. Pusat Data dan Informasi Kementrian Lingkungan Hidup dan Kehutanan republik Indonesia.

Koontz, T. M., \& Thomas, C. W. (2018). Use of science in collaborative environmental management: Evidence from local watershed partnerships in the Puget Sound. Environmental Science and Policy, 88(October), 17-23. https://doi.org/10.1016/ j.envsci.2018.06.007

Margerum, R. D. (2008). A typology of collaboration efforts in environmental management. Environmental Management, 41(4), 487-500. https:// doi.org/10.1007/s00267-008-90679

McDonald, S., \& Young, S. (2012). Cross-sector collaboration shaping Corporate Social Responsibility best practice within the mining industry. Journal of Cleaner Production, 37, 54-67. https://doi.org/10.1016/j.jclepro.2012.06.007

Migdar, A. S. (2019). Strategi Pemerintah Daerah Dalam Menangani Dampak Pembangunan Kawasan Industri Di Kabupaten Karawang Tahun 2015-2018. Universitas Padjadjaran . Mohajan, H. K. (2018). Qualitative Research Methodology in Social Sciences and Related Subjects Qualitative Research Methodology in Social Sciences and Related Subjects. UTC Journal of Economic Development, Environment and People, 85654(85654), 1. https:/ /mpra.ub.uni-muenchen.de/85654/1/MPRA_paper_85654.pdf

Muzwardi, E. P. P. R. R. R. S. A. (2018). Collaborative Governance Dalam Tata Kelola Hutan Berbasis Masyarakat. Lembaga Penelitian, Publikasi dan Pengabdian Masyarakat (LP3M) Universitas Muhammadiyah Yogyakarta.

Newig, J., Challies, E. D., Jager, N. W., Kochskaemper, E., \& Adzersen, A. (2018). The Environmental Performance of Participatory and Collaborative Governance: A Framework of Causal Mechanisms. Policy Studies Journal, 46(2), 269-297. https:// doi.org/10.1111/psj.12209

Parés, M., Boada, J., Canal, R., Hernando, E., \& Martínez, R. (2017). Challenging collaborative urban governance under austerity: How local governments and social organizations deal with housing policy in Catalonia (Spain). Journal of Urban Affairs, 39(8), 1066-1084. https:/ / doi.org/10.1080/07352166.2017.1310531

Pidji Astuti, Nanik Setyowati, M. A. A. (2017). Analysis of Local Government PolicyBased Society in The Brantas River Basin on nviroenmental Mangaement in Easr Java. Junral Cakrawala, 11(1), 67-81. 
Purnaweni, H. (2014). Kebijakan Pengelolaan Lingkungan Di Kawasan Kendeng Utara Provinsi Jawa Tengah. Jurnal Ilmu Lingkungan, 12(1), 53. https:// doi.org/10.14710/ jil.12.1.53-65

Sajwani, A., \& Nielsen, Y. (2019). The Environmental Management System Framework of the Industrial Facility: A Case Study in the UAE Aluminium Industry. J Environ Hazard, 2(1), 116.

Temmy Wikanungrum, Bambang Pramudya, E. N. (2015). Kebijakan Pengelolaan Lingkungan Kawasan Industri Sesuai Proper KLHK Peringkat Hijau. Jurnal Pengelolaan Sumberdaya Alam Dan Lingkungan (Journal of Natural Resources and Environmental Management), 5 No.2. https://doi.org/https://doi.org/10.29244/jpsl.5.2.111

UNEP. (2020). Summary Report Waste Management.

Wang, L., Tong, J., \& Li, Y. (2019). River Chief System (RCS): An experiment on crosssectoral coordination of watershed governance. Frontiers of Environmental Science and Engineering, 13(4), 10-12. https://doi.org/10.1007/s11783-019-1157-9

Weir, M., Rongerude, J., \& Ansell, C. K. (2009). Collaboration Is Not Enough. In Urban Affairs Review (Vol. 44, Issue 4). https:// doi.org/10.1177/1078087408322590

Wikaningrum, T. (2016). Kajian Keberlajutan Pengelolaan Lingkungan Kawasan Industri Studi Kasus di Kawasan Industri Jababeka Bekasi. Journal of Env. Engineering \& Waste Management, 1(2), 75-83.

Wikaningrum, T., Pramudya N, B., \& Noor, E. (2015). The Policy of Industrial Estate Environmental Management Complying to the Green Rating of "PROPER KLHK" (The Case Study in Jababeka Industrial Estate). Journal of Natural Resources and Environmental Management, 5(2), 111-120. https://doi.org/10.19081/jps1.5.2.111

Woldesenbet, W. G. (2020). Analyzing multi-stakeholder collaborative governance practices in urban water projects in Addis Ababa City: procedures, priorities, and structures. Applied Water Science, 10(1), 1-19. https://doi.org/10.1007/s13201-0191137-z

Z O, O., O O E, J., T A, A., \& A M, T. (2018). Environmental Pollution and Related Hazards at Agbara Industrial Area, Ogun State. Scientific Reports, 8(1), 6482. https:/ / doi.org/10.1038/s41598-018-24810-4 